\title{
IMPLEMENTASI KEBIJAKAN PEMERINTAH TERHADAP DISIPLIN APARATUR SIPIL NEGARA PADA KANTOR KELURAHAN BARANTI KABUPATEN SIDENRENG RAPPANG
}

\author{
Andi Asmawati \\ IImu Pemerintahan, Fakultas IImu Sosial dan IImu Politik, Universitas Muhammadiyah Sidenreng Rappang \\ andiasmawatiar4315091f1@gmail.com
}

\begin{abstract}
Abstrak
Penelitian ini bertujuan untuk mengetahui Implementasi Kebijakan Pemerintah terhadap Disiplin Aparatur Sipil Negara pada Kantor Kelurahan di Kecamatan Baranti Kabupaten Sidenreng Rappang. Teknik pengambilan sampel menggunakan teknik sampling jenuh dengan jumlah sampel sebanyak 23 orang. Teknik pengumpulan data menggunakan observasi, wawancara, kuesioner, dan studi kepustakaan. Teknik analisis data kuantitatif yang digunakan yaitu analisis tabulasi frekuensi dan analisis regresi sederhana dengan bantuan program SPSS 16.0 for windows dan Skala Likert.Berdasarkan dari hasil olah kuesioner diperoleh rekapitulasi dari variabel implementasi kebijakan pemerintah, diukur melalui indikator tepat kebijakan, tepat pelaksana, tepat target, tepat lingkungan, dan tepat proses, sebesar $41 \%$ termasuk dalam kategori "cukup baik". Rekapitulasi dari variabel disiplin aparatur sipil negara diukur melalui indikator disiplin waktu, disiplin peraturan, disiplin tanggung jawab, sebesar 33\% termasuk dalam kategori "kurang baik". Berdasarkan hasil olahan analisis regresi sederhana menggunakan SPSS 16.0 for windows, dengan Model Summary diperoleh nilai sebesar 41\% dengan kategori "cukup baik".
\end{abstract}

Kata Kunci : Implementasi dan Disiplin

\begin{abstract}
This study aims to determine the Implementation of Government Policy on the Discipline of State Civil Apparatus in the Village Office in Baranti District, Sidenreng Rappang Regency. The sampling technique used a saturated sampling technique with a total sample of 23 people. The technique of collecting data uses observation, interviews, questionnaires, and literature studies. Quantitative data analysis techniques used are frequency tabulation analysis and simple regression analysis with the help of SPSS 16.0 for windows and Likert Scale programs.Based on the results of the questionnaire, the recapitulation of the variable implementation of government policy was obtained, measured through appropriate policy indicators, appropriate implementers, right targets, right environment, and appropriate processes, $41 \%$ included in the "good enough" category. The recapitulation of the disciplinary variables of the state civil apparatus is measured through indicators of time discipline, regulatory discipline, responsibility discipline, 33\% included in the "less good" category. Based on the results of processed simple regression analysis using SPSS 16.0 for windows, the Model Summary obtained avalue of $41 \%$ with the category "good enough".
\end{abstract}

Keywords: Implementation and Dicipline

PRAJA | Volume 8| Nomor 3| Edisi Februari 2020 


\section{A. PENDAHULUAN}

Pegawai Negeri Sipil (PNS) merupakan setiap warga Negara Republik Indonesi yang memenuhi syarat yang telah ditentukan serta diangkat sebagai Aparatur sipil Negara (ASN) secara tetap oleh pejabat pembina kepegawaian untuk menduduki suatu jabatan pemerintahan, serta digaji sesuai dengan ketentuan perundangundangan yang berlaku. Dalam menjalankan tugas dan tanggung jawabnya maka setiap Pegawai Aparatur Sipil Negara (ASN) wajib mendisiplinkan dirinya dalam melaksanakan tugas dan tanggung jawabnya serta dengan jabatan yang dijalankan sesuai dengan aturan dan ketentuan perundang-undangan tentang disiplin yang berlaku.

Undang-Undang Nomor 5 Tahun 2014 tentang Aparatur Sipil Negara di terbitkan dengan tujuan untuk mewujudkan pelaksanaan cita-cita bangsa dan negara sebagaimana yang tertera dalam Pembukaan Undang-Undang Dasar Negara Republik Indonesia Tahun 1945 sehingga dengan hal tersebut maka perlu adanya sumber daya aparatur sipil negara yang memiliki integritas, profesional, netral dan bebas dari intervensi politik serta bersih dari praktik KKN. UndangUndang Aparatur Sipil Negara diterbitkan untuk menggantikan Undang-Undang Nomor 8 Tahun 1974 tentang Pokok-Pokok Kepegawaian sebagaimana telah diubah dengan Undang-Undang Nomor 43 Tahun 1999 tentang Perubahan atas UndangUndang Nomor 8 Tahun 1974 tentang PokokPokok Kepegawaian karena sudah tidak sesuai dengan tuntutan nasional dan tantangan global. Aturan tersebut perlu ditetapkan penyelenggara pemerintah negara atau Aparatur Sipil Negara sebagai profesi yang memiliki kewajiban mengelola dan mengembangkan dirinya dan wajib mempertanggungjawabkan kinerjanya dengan berpedoman pada aturan tersebut sebagai bagian dari tindakan disiplin untuk dapat menghindari jatuhan sanksi atau hukuman yang mungkin dapat dijatuhkan sebagai kompensasi atau ganti rugi dari ketidak disiplinan Aparatur Sipil Negara yang diberikan wewenang untuk menjalankan amanat undang-undang tersebut sebagai bagian dari koreksi dan mendidik PNS.

Setiap Aparatur Sipil Negara (ASN), dalam melaksanakan tugas dan tanggungjawab yang dijalankan harus mengetahui dan memahami norma-norma hukum dan kode etik serta tata tertib sebagai Aparatur Sipil Negara termasuk peraturan disiplin PNS yang berlaku. Undang-Undang Nomor 5 Tahun 2014 Tentang Aparatur Sipil Negara khususnya pada Bab VIII Manajemen PNS Bagian Ketiga Paragraf 11 Pasal 86 ayat 1 yang menyatakan "Untuk menjamin terpeliharanya tata tertib dalam kelancaran pelaksanaan tugas, PNS wajib mematuhi disiplin PNS". Ayat 2 yang menyatakan "Instansi Pemerintah wajib melaksanakan penegakan disiplin terhadap PNS serta melaksanakan berbagai upaya peningkatan disiplin". Maksud dari Disiplin PNS di jelaskan dengan rinci pada Peraturan Pemerintah Nomor 53 Tahun 2010 Tentang Disiplin Pegawai Negeri Sipil khususnya pasal 3 ayat 11 yang menyatakan "Setiap Pegawai Negeri Sipil wajib masuk kerja dan menaati ketentuan jam kerja". Menurut Penjelasan pasal 3 ayat 11 tersebut bahwa yang dimaksud dengan kewajiban untuk "Masuk kerja dan menaati ketentuan jam kerja" adalah setiap Pegawai Negeri Sipil wajib datang, melaksanakan tugas, dan pulang sesuai ketentuan jam kerja serta tidak berada di tempat umum yang bukan karena urusan kedinasan. Apabila berhalangan hadir wajib memberitahukan kepada pejabat yang berwenang. Keterlambatan masuk kerja dan/atau pulang cepat dihitung secara kumulatif dan dikonversi $7 \frac{1}{2}$ (tujuh setengah) jam sama dengan 1 (satu) hari tidak masuk kerja. Seperti yang tertera dalam Surat Edaran Bupati Sidenreng Rappang Nomor: 061/091/Org yang tertulis bahwa berdasarkan Peraturan Pemerintah Nomor 53 Tahun 2010 tentang Disiplin Pegawai Negeri Sipil dan hasil rapat koordinasi para kepala SKPD dengan Bupati Sidenreng Rappang yang antara lain mengamanatkan untuk meningkatkan kembali disiplin kerja PNS terutama pelaksanaan apel pagi dan apel pulang bagi pegawai lingkup SKPD se Kabupaten Sidenreng Rappang, sehubung dengan hal tersebut, ditegaskan kembali hal-hal sebagai berikut :

1) Jumlah jam kerja efektif dalam seminggu adalah 37,5 jam (tiga puluh tujuh jam tiga puluh menit).

2) Jam kerja untuk hari senin $s / d$ kamis adalah pukul 08.00 wita -16.30 wita, dan hari jum'at pukul $08.00-17.00$ wita.

3) Apel pagi dilaksanakan 15 (lima belas) menit sebelum jam kerja dimulai dan apel pulang dilaksanakan 15 (lima belas) menit sebelum jam kerja berakhir. 
4) Pelaksanaan apel pagi untuk hari senin s/d kamis, dimulai pada pukul 07.45 wita dan apel pulang pada pukul 16.15 wita dan hari jum'at apel pagi dimulai pada pukul 07.45 dan apel pulang pada pukul 16.45 wita.

5) Kepada seluruh ASN / PNS, baik pejabat Eselon II, III, IV dan staf untuk mengikuti Apel Pagi dan Apel Pulang setiap hari kerja serta upacara pada setiap hari senin sesuai dengan ketentuan dalam peraturan bupati sidenreng rappang nomor 16 tahun 2017 tentang Pakaian Dinas Aparatur Sipil Negara di Lingkungan Pemerintah Kabupaten Sidenreng Rappang

Efektivitas pelaksanaan kebijakan merupakan pengukuran terhadap tercapainya tujuan kebijakan yang telah dirumuskan sebelumnya. Efektivitas implementasi kebijakan berkaitan dengan sejauh mana implementasi yang dilakukan mencapai tujuan kebijakan yang diharapkan. Keberhasilan implementasi kebijakan akan ditentukan oleh banyak variabel atau faktor, dan masingmasing variabel tersebut saling berhubungan satu sama lain. untuk memperkaya pemahaman kita tentang berbagai variabel yang terlibat didalam implementasi, maka dari itu ada pembatasan dalam penelitian ini maka peneliti memilih pendekatan yang dikemukakan oleh Riant Nugroho (2012: 707710) yang mengemukakan bahwa terdapat 5 (lima) "tepat" yang perlu dipenuhi dalam hal keefektifan implementasi kebijakan. Yakni: Tepat kebijakan, Tepat pelaksananya, Tepat target, Tepat lingkungan, Tepat proses.

Senada yang dikatakan oleh salah satu Kepala Kelurahan yang ada di Kecamatan Baranti mengatakan bahwa ada beberapa Aparatur Sipil Negara yang datang meng absen kemudian pulang sehingga tugas dan kewajibannya tidak terlaksana. Seperti halnya keluar dan masuk kerja tidak sesuai dengan waktu yang seharusnya masuk jam 08.00 wita dan pulang jam 16.30 wita namun yang terjadi dilapangan masih adanya Aparatur Sipil Negara (ASN) yang setelah absen elektronik di Kantor Kecamatan langsung kembali kerumahnya atau kepasar terlebih dahulu tidak langsung ke Kantor Kelurahan masing-masing untuk menjalankan tugas dan kewajibannya, dan juga adanya Aparatur Sipil Negara (ASN) yang meninggalkan atau pulang kantor tidak pada waktu jam pulang kantor dan setelah tiba jam pulang kantor barulah kemudian Aparatur Sipil
Negara (ASN) tersebut ke Kantor Kecamatan untuk absen elektronik pulang.

Berdasarkan latar belakang tersebut diatas dimana adanya penyimpangan yang dilakukan oleh Aparatur Sipil Negara, maka penulis tertarik untuk melakukan kajian khusus mengenai disiplin ASN dalam suatu judul penelitian yaitu implementasi kebijakan pemerintah terhadap disiplin aparatur sipil negara pada kantor kelurahan di Kecamatan Baranti Kabupaten Sidenreng Rappang dengan tujuan untuk mengetahui Implementasi Kebijakan Pemerintah pada Kantor Kelurahan di Kecamatan Baranti Kabupaten Sidenreng Rappang, untuk mengetahui Disiplin Aparatur Sipil Negara pada Kantor Kelurahan di Kecamatan Baranti Kabupaten Sidenreng Rappang dan untuk mengetahui Implementasi Kebijakan Pemerintah terhadap Disiplin Aparatur Sipil Negara pada Kantor Kelurahan di Kecamatan Baranti Kabupaten Sidenreng Rappang.

\section{Implementasi Kebijakan}

Ripley dan Franklin dalam (Winarno, 2012) berpendapat bahwa implementasi adalah apa yang terjadi setelah undangundang ditetapkan yang memberikan otoritas program, kebijakan, keuntungan (benefit), atau suatu jenis keluaran yang nyata (tangible output). Istilah implementasi menunjuk pada sejumlah kegiatan yang mengikuti pernyataan maksud tentang tujuan-tujuan program dan hasil-hasil yang diinginkan oleh para pejabat pemerintah. Implementasi mencakup tindakan-tindakan (tanpa tindakan-tindakan) oleh berbagai aktor, khususnya para birokrat, yang dimakasudkan untuk membuat program berjalan.Carl J Federick dalam (Agustino, 2016) mendefinisikan kebijakan sebagai serangkaian tindakan/kegiatan yang diusulkan seseorang, kelompok atau pemerintah dalam suatu lingkungan tertentu dimana terdapat hambatan-hambatan (kesulitan-kesulitan) dan kesempatan-kesempatan terhadap pelaksanaan usulan kebijaksanaan tersebut dalam rangka mencapai tujuan tertentu.

Van Meter dan Van Horn dalam (Agustino, 2016), mendefinisikan Implementasi Kebijakan, sebagai Tindakantindakan yang dilakukan baik oleh individuindividu atau pejabat-pejabat atau kelompokkelompok pemerintah atau swasta yang diarahkan pada tercapainya tujuan-tujuan yang telah digariskan dalam keputusan kebijaksanaan. Menurut Nugroho (2012) 
bahwa terdapat lima "tepat" yang perlu dipenuhi dalam hal keefektifan implementasi kebijakan.

a. Tepat kebijakan. Carl J Federick dalam (Agustino, 2016) mendefinisikan kebijakan sebagai serangkaian tindakan/kegiatan yang diusulkan seseorang, kelompok atau pemerintah dalam suatu lingkungan tertentu dimana terdapat hambatanhambatan (kesulitan-kesulitan) dan kesempatan-kesempatan terhadap pelaksanaan usulan kebijaksanaan tersebut dalam rangka mencapai tujuan tertentu.Ketepatan kebijakan dinilai dari sejauh mana kebijakan yang ada telah bermuatan hal-hal yang memang memecahkan masalah yang hendak dipecahkan. Apakah kebijakan tersebut sudah dirumuskan sesuai karakter masalah yang hendak dipecahkan. Apakah kebijakan dibuat oleh lembaga yang mempunyai kewenangan (misi kelembagaan) yang sesuai dengan karakter kebijakan.

b. Tepat pelaksananya,Menurut (Abdullah Ramdhani, 2017) Pelaksanaan kebijakan secara sederhana adalah pelaksanaan atau penerapan suatu kebijakan.Pelaksanaan kebijakan bermuara pada aktifitas, aksi, tindakan, atau mekanisme yang dibingkai pada suatu sistem tertentu. Pelaksanaan kebijakan merupakan suatu kegiatan terencana yang dilakukan secara sungguh-sungguh berdasarkan acuan norma tertentu yang diarahkan untuk mencapai tujuan tertentu. Terdapat tiga lembaga yang dapat menjadi implementor, yaitu pemerintah, kerjasama antar pemerintah dan masyarakat/swasta, atau implementasi kebijakan yang bersifat monopoli.

c. Tepat target,

Target adalahmengevaluasi daya tarik masing - masing segmen dengan menggunakan variable - variable yang bisa menguantifikasi kemungkinan permintaan dari setiap segmen, biaya melayani setiap segmen, biaya memproduksi produk dan jasa yang diinginkan pelanggan, dan kesesuaian antara kompetensi inti perusahaan dan peluang pasar (Tjiptono, 2007). Menurut Kamus besar Bahasa Indonesia Target adalah "Sasaran atau batas ketentuan yang telah ditetapkan untuk dicapai".Apakah target yang diintervensi sesuai dengan yang direncanakan, tidak tumpang tindih atau bertentangan dengan intervensi kebijakan lain. Apakah target dalam kondisi siap diintervensi atau tidak. Dan apakah intervensi implementasi kebijakan bersifat baru atau memperbarui implementasi kebijakan sebelumnya.

d. Tepat lingkungan,Lingkungan hidup ialah wilayah yang merupakan tempat berlangsungnya bermacam-macam interaksi sosial antara berbagai kelompok beserta pranatanya dengan simbol \& nilai (Purba, 2005).Lingkungan dalam hal ini terbagi menjadi lingkungan internal kebijakan yang berkaitan dengan interaksi diantar perumus kebijakan dan pelaksana kebijakan dengan lembaga lain yang terkait. Dan lingkungan eksternal kebijakan yang berkaitan dengan persepsi publik akan kebijakan dan implementasi kebijakan.

e. Tepat proses,Proses adalah suatu cara, metode maupun teknik untuk penyelenggaraan atau pelaksanaan dari suatu hal tertentu" (Ahyari, 2002). Pengertian proses yang dikemukakan oleh para ahli, antar lain dikemukakan oleh Soewarno Handayaningrat dalam bukunya yang berjudul "Pengantar Studi IImu Administrasi dan Manajemen" mengatakan bahwa Proses adalah sesuatu tuntutan perubahan dari suatu peristiwa perkembangan sesuatu yang dilakukan secara terus-menerus. (Handayaningrat, 2006). Terdiri atas tiga proses. Yaitu Policy Acceptance, publik memahami kebijakan sebagai aturan dan pemerintah memahaminya sebagai tugas yang harus dilaksanakan. Policy adoption, publik menerima kebijakan sebagai aturan dan pemerintah menerimanya sebagai tugas yang harus dilaksanakan. Strategic Readiness, publik siap melaksanakan atau menjadi bagian dari kebijakan, dan birokrat siap menjadi pelaksana kebijakan.

\section{Faktor-faktor yang Mempengaruhi Implementasi Kebijakan \\ Menurut George C. Edward} III(Zainuddin, 2017) Faktor penentu Implementasi Kebijakan akan berjalan dengan baik atau tidak, karena dipengaruhi oleh empat faktor yaitu :
a. Faktor Komunikasi
Variabel
pertama
yang
mempengaruhi keberhasilan implementasi 
suatu kebijakan menurut George C. Edward III dalam (Agustino, 2016) adalah komunikasi. Komunikasi menurutnya sangat menentukan keberhasilan pencapaian tujuan dari implementasi kebijakan publik. Implementasi yang efektif terjadi apabila para pembuat keputusan sudah mengetahui apa yang mereka kerjakan. Pengetahuan atas apa yang akan mereka kerjakan dapat berjalan apabila komunikasi berjalan dengan baik, sehingga setiap keputusan kebijakan dan peraturan implementasi harus ditansmisikan (atau dikomunikasikan) kepada bagian personalia yang tepat. Kebijakan yang dikomunikasikan harus tepat, akurat, dan konsisten. Komunikasi (atau pentransmisian informasi) diperlukan agar para pembuat keputusan dan para implementor akan semakin konsisten dalam melaksanakan setiap kebijakan yang ditetapkan dalam masyarakat.

b. Faktor Sumber Daya

Variabel kedua yang mempengaruhi keberhasilan implementasi suatu kebijakan adalah sumber daya. Sumber Daya merupakan hal penting lainnya dalam mengimplementasikan kebijakan, menurut George C. Edward III dalam (Agustino, 2016). Indikator sumber daya terdiri dari beberapa elemen, yaitu :

1) Staf; sumber daya utama dalam implementasi kebijakan adalah staf. Kegagalan yang sering terjadi dalam implementasi kebijakan salah satunya disebabkan oleh karena staf yang tidak mencukupi, memadai, ataupun tidak kompoten dibidangnya. Penambahan jumlah staf dan implementor saja tidak cukup, tetapi diperlukan juga kecukupan staf dengan keahlian dan kemampuan yang diperlukan (kompoten dan kapabel) dalam mengimplementasikan kebijakan atau melaksanakan tugas yang diinginkan oleh kebijakan itu sendiri.

2) Informasi; dalam implementasi kebijakan, informasi mempunyai dua bentuk, yaitu pertama informasi yang berhubungan dengan cara melaksanakan kebijakan. Implementor harus mengetahui apa yang harus mereka lakukan saat mereka diberi perintah. Kedua, informasi mengenai data kepatuhan dari para pelaksana terhadap peraturan dan regulasi pemerintah yang telah ditetapkan. Implementer harus mengetahui apakah orang yang terlibat di dalam pelaksanaan kebijakan tersebut patuh terhadap hukum.

3) Wewenang; pada umumnya kewenangan harus bersifat formal agar perintah dapat dilaksanakan. Kewenangan merupakan otoritas atau legitimasi bagi para pelaksana dalam melaksanakan kebijakan yang ditetapkan secara politik. Kewenangan akan nihil, ketika kekuatan para implementor dimata publik tidak terlegitimasi, sehingga dapat menggagalkan proses implementasi kebijakan. Tetapi dalam konteks yang lain, ketika wewenang formal tersebut ada, maka sering terjadi kesalahan dalam melihat efektivitas kewenangan. Disatu pihak, efektivitas akan menyurut manakala wewenang diselewengkan oleh para pelaksana demi kepentingannya sendiri atau demi kepentingan kelompoknya.

4) Fasilitas; fasilitas fisik juga merupakan faktor penting dalam implementasi kebijakan. Implementor mungkin memiliki staf yang mencukupi, mengerti apa yang harus dilakukan dan memiliki wewenang untuk melaksanakan tugasnya, tetapi tanpa adanya fasilitas pendukung (sarana dan prasarana) maka implementasi kebijakan tersebut tidak akan berhasil.

\section{c. Sikap Pelaksana (Disposisi)}

Variabel ketiga yang memengaruhi keberhasilan implementasi kebijakana adalah disposisi. Hal-hal penting yang perlu dicermati pada variabel disposisi, menurut George C. Edward III dalam (Agustino, 2016) adalah :

1) Pengangkata birokrasi; disposisi atau sikap pelaksana akan menimbulkan hambatan-hambatan yang nyata terhadap implementasi kebijakan apabila personil yang ada tidak melaksanakan kebijakan-kebijakan yang diinginkan oleh pejabat-pejabat tinggi. Pemilihan dan pengangkatan personil pelaksana kebijakan haruslah orangorang yang memiliki dedikasi pada kebijakan yang telah ditetapkan.

2) Insentif; Edward menyatakan bahwa salah satu teknik yang disarankan untuk mengatasi masalah kecendrungan para 
pelaksana adalah dengan memanipulasi insentif. Pada umumnya orang bertindak menurut kepentingan mereka sendiri, maka memanipulasi insentif oleh para pembuat kebijakan memengaruhi tindakan para pelaksana kebijakan, dengan cara menambah keuntungan atau biaya tertentu mungkin akan menjadi faktor pendorong yang membuat para pelaksana kebijakan melaksanakan perintah dengan baik. Hal ini dilakukan sebagai upaya memenuhi kepentingan pribadi (self interst) atau organisasi.

d. Struktur Birokrasi

Menurut Edward III dalam (Agustino, 2016), yang memengaruhi keberhasilan implementasi kebijakan publik adalah struktur birokrasi. Walaupun sumber daya untuk melaksanakan suatu kebijakan tersedia, atau para pelaksana kebijakan mengetahui apa yang seharusnya dilakukan, dan mempunyai keinginan untuk melaksanakan suatu kebijakan, kemungkinan kebijakan tersebut tidak dapat dilaksanakan atau direalisasikan karena terdapatnya kelemahan dalam struktur birokrasi. Kebijakan yang begitu kompleks menuntut adanya kerjasama banyak orang, ketika struktur birokrasi tidak kondusif pada kebijakan yang tersedia, maka hal ini akan menyebabkan sumber daya menjadi tidak efektif dan menghambat jalannya kebijakan. Birokrasi sebagai pelaksana sebuah kebijakan harus dapat mendukung kebijakan yang telah diputuskan secara politik dengan jalan melakukan koordinasi dengan baik.Dua karakteristik, menurut Edward III, yang dapat mendongkrak kinerja struktur birokrasi/organisasi kearah yang lebih baik, yaitu dengan melakukan :

1) Standar Operating Prosedures (SOP); adalah suatu kegiatan rutin yang memungkinkan para pegawai (atau pelaksana

kebijakan/administrator/birokrat) untuk melaksanakan kegiatan-kegiatannya setiap hari sesuai dengan standar yang ditetapkan atau standar minimum yang dibutuhkan.

2) Fragmentasi; adalah upaya penyebaran tanggung jawab kegiatan-kegiatan atau aktivitas-aktivitas pegawai diantara beberapa unit kerja.

\section{Disiplin Aparatur Sipil Negara}

Gordon S.(Moenir, 2010) disiplin dalam pengertian yang utuh adalah suatu kondisi dan sikap yang ada pada semua anggota organisasi yang tunduk dan taat pada aturan organisasi. Disiplin menurut Moenir adalah suatu bentuk ketaatan terhadap aturan, baik tertulis maupun tidak tertulis. Moenir berpendapat bahwa:"Dalam pelaksanaan tugas/pekerjaan disiplin terdiri atas dua jenis disiplin, yaitu disiplin waktu dan disiplin perbuatan. Kedua jenis disiplin tersebut merupakan kesatuan yang tak dapat dipisahkan Serta saling mempengaruhi. Disiplin waktu tanpa disertai disiplin kerja tidak ada artinya, dengan kata lain tidak ada hasil sesuai dengan ketentuan organisasi. Menurut Robbins (2005), kriteria yang dipakai dalam disiplin kerja dapat dikelompokkan menjadi tiga indikator disiplin kerja yaitu di antaranya:

a. Disiplin waktu : disiplin waktu disini diartikan sebagai sikap atau tingkah laku yang menunjukkan ketaatan terhadap jam kerja yang meliputi kehadiran dan kepatuhan karyawan pada jam kerja, karyawan melaksanakan tugas dengan tepat waktu dan benar.

b. Disiplin peraturan : peraturan maupun tata tertib yang tertulis dan tidak tertulis dibuat agar tujuan suatu organisasi dapat dicapai dengan baik. Untuk itu dibutuhkan sikap dari karyawan terhadap komitmen yang telah ditetapkan tersebut. Kesetiaan disini berarti taat dan patuh dalam melaksanakan perintah dari atasan dan peraturan, tata tertib yang telah ditetapkan. Serta ketaatan karyawan dalam menggunakan kelengkapan pakaian seragam yang telah ditentukan organisasi atau perusahaan.

c. Disiplin tanggung jawab : salah satuwujud tanggung jawab karyawan adalah penggunaan dan pemeliharaan peralatan yang sebaik-baiknya sehingga dapat menunjang kegiatan kantor berjalan dengan lancar. Serta adanya kesanggupan dalam menghadapi pekerjaan yang menjadi tanggung jawabnya sebagai seorang karyawan.

\section{B. METODE PENELITIAN}

Penelitian ini dilaksanakan pada Kantor Kelurahan di Kecamatan Baranti Kabupaten Sidenreng Rappang.Jenis penelitian yang digunakan pada penelitian ini adalah jenis penelitian Asosiatif kuantitatif,dengan metode 
ini diharapkan dapat memberikan gambaran secara cermat, jelas dan objektif mengenai masalah yang akan diteliti. Adapun dasar penelitian berdasarkan metode ini adalah penelitian survei. Menurut sugiyono (2014: 12) penelitian survei adalah penelitian yang dilakukan pada populasi besar maupun kecil tetapi data yang dipelajari adalah data dari sampel yang diambil dari populasi tersebut sehingga ditemukan kejadian relatif, distribusi, dan hubungan antar variabel (sosiologis maupun psikologis). Penelitian survei dilakukan dengan menggunakan kuesioner (angket) sebagai alat penelitian atau pengumpulan data di lapangan.

Adapun populasi dalam penelitian ini adalah Aparatur Sipil Negara Kelurahan Baranti 4 orang, Aparatur Sipil Negara Kelurahan Duampanua 4 orang, Aparatur Sipil Negara Kelurahan Manisa 6 orang, Aparatur Sipil Negara Kelurahan Panreng 4 orang, Aparatur Sipil Negara Kelurahan Benteng 5 orang, dimana 4 orang Lurah yang menjadi informan, Sedangkan teknik penarikan sampel yang digunakan pada penelitian ini adalah Sampling Jenuh (Sensus). Menurut (Ahmad, 2015) dalam bukunya pengertian Sampling Jenuh atau Definisi Sampling Jenuh adalah teknik penentuan sampel bila semua anggota populasi digunakan sebagai sampel. Hal ini sering dilakukan bila jumlah populasi relatif kecil, kurang dari 30 orang, atau penelitian yang ingin membuat generalisasi dengan kesalahan yang sangat kecil.

Teknik pengumpulan data menggunakan Observasi, Interview, Kuesioner, dan Studi Kepustakaan, sedangkanteknik analisis data yang digunakan adalah Statistik Deskriptif analisis yang digunakan dalam penelitian ini adalah analisis regresi sederhana. Koefisien diterminasi digunakan untuk mengukur seberapa jauh kemampuan model dalam menerangkan variasi variabel dependen, Langkah terakhir adalah mendeskripsikan hasil analisis data sehingga pada akhirnya dapat ditarik sebuah kesimpulan. Data yang diperoleh melalui kuesioner dianalisis dengan menggunakan Skala Likert.

\section{HASIL DAN PEMBAHASAN}

Baranti adalah sebuah Kecamatan di Kabupaten Sidenreng Rappang, Sulawesi Selatan, Indonesia. Kelurahan Baranti merupakan Ibu Kota Kecamatan Baranti. Selain Kelurahan Baranti, terdapat pula Kelurahan Duampanua, Kelurahan Panreng,
Kelurahan Manisa, Kelurahan Benteng, Desa Sipodeceng, Desa Tonronge, Desa Tonrong Rijang, dan Desa Passeno.Implementasi Kebijakan Pemerintah terhadap Disiplin Aparatur Sipil Negara pada Kantor Kelurahan di Kecamatan Baranti Kabupaten Sidenreng Rappang yang berupa pertanyaan yang diberikan kepada responden pada kuesioner yang disebarkan sebagai cara untuk memudahkan dalam memberikan analisa mengenai hasil penelitian yang dilakukan pada Kantor Kelurahan di Kecamatan Baranti Kabupaten Sidenreng Rappang, yang disebarkan pada 23 orang responden sebagai subjek penelitian skripsi ini.

Berdasarkan hasil observasi, wawancara, dan kuesioner yang telah disebar kepada responden maka dapat diperoleh informasi tentang Implementasi Kebijakan Pemerintah terhadap Disiplin Aparatur Sipil Negara pada Kantor Kelurahan di Kecamatan Baranti Kabupaten Sidenreng Rappang. Penelitian tersebut diperoleh informasi yang dapat dijadikan bahan penelitian dan kesimpulan. Data dan informasi yang diperoleh melalui hasil kuesioner tersebut kemudian dianalisa sebagai berikut :

1. Implementasi Kebijakan Pemerintah (X)

Hasil analisis penelitian Implementasi Kebijakan Pemerintah pada Kantor Kelurahan di Kecamatan Baranti Kabupaten Sidenreng Rappang secara keseluruhan dapat dilihat pada tabel akumulasi berikut iniTanggapan responden mengenai Implementasi Kebijakan Pemerintah pada Kantor Kelurahan di Kecamatan Baranti Kabupaten Sidenreng Rappang. Dari ke lima indikator antara lain tepat kebijakan, tepat pelaksana, tepat target, tepat lingkungan, tepat proses, diperoleh ratarata persentase sebesar $41 \%$ berada pada kategori Cukup Baik.Untuk memperkuat penilaian responden seperti yang diuraikan di atas, peneliti melakukan penelusuran data melalui wawancara dengan Lurah Baranti atas nama Herfan Mappajeppu, S.IP mengenai Implementasi Kebijakan Pemerintah pada Kantor Kelurahan Baranti, pada tanggal 10 Mei 2019 Pukul 10:47 Wita beliau mengatakan bahwa:

Pada UU No. 5 tahun 2014 tentang Aparatur Sipil Negara pasal 86 ayat 2 yang berbunyi "Instansi pemerintah wajib melaksanakan penegakan disiplin terhadap PNS serta melaksanakan berbagai upaya peningkatan disiplin" dan kemudian pemerintah merbitkan aturan jam kerja untuk 
ASN yang di edarkan ke tiap Kecamatan dan Kelurahan akan tetapi kebijakan tersebut belum sepenuhnya diterapkan oleh ASN"Berdasarkan hasil rekapitulasi dan wawancara dengan Kepala Kelurahan Baranti, maka peneliti menyimpulkan bahwa implementasi kebijakan pemerintah mengenai jam kerja aparatur sipil negara, aparatur sipil negara belum sepenuhnya melaksanakan aturan jam kerja.

2. Disiplin Aparatur Sipil Negara (Y)

Hasil analisis penelitian Disiplin Aparatur

Sipil Negara pada Kantor Kelurahan di Kecamatan Baranti Kabupaten Sidenreng Rappang secara keseluruhan dapat dilihat pada tabel akumulasi berikut ini:Tanggapan responden mengenai Disiplin Aparatur Sipil Negara pada Kantor Kelurahan di Kecamatan Baranti Kabupaten Sidenreng Rappang. Dari tiga indikator antara lain disiplin waktu, disiplin peraturan, disiplin tanggung jawab, diperoleh rata-rata persentase sebesar $33 \%$ atau berada pada kategori kurang baik.

berbicara kedisiplinan Aparatur Sipil Negara mengenai aturan jam kerja pemerintah telah mengeluarkan aturan jam kerja ASN yaitu 5 hari kerja dan dimulai pada pukul 08.00-16.30 untuk hari senin s/d kamis dan pukul 08.00-17.00 untuk hari jumat namun masih ada beberapa ASN yang masuk kantor tidak pada jam yang seharusnya atau terlambat dengan alasan pribadi.Melihat aturan yang dikeluarkan pemerintah tentang aturan jam kerja ASN masih ada beberapa ASN yang datang absen kedian pulang sehingga tugas dan kewajibannya tidak terlaksana. Pemerintah mengeluarkan aturan jam kerja untuk ASN bahwa jam kerja dimulai pada pukul 08.00-16.30 namun aturan tersebut belum diterapkan dengan baik masih ada beberapa ASN yang datang jam 9 atau 10 dan pulang sebelum jam pulang kantor berakhir. Aturan untuk jam kerja ASN yang telah diedarkan oleh pemerintah disetiap kelurahan akan tetapi masih ada beberapa ASN yang tidak menaati aturan tersebut.

Adapun keseluruhan frekuensi dari variabel $X$ (Implementasi Kebijakan Pemerintah) adalah 234, Untuk mengetahui jumlah persentase ideal, maka dapat dihitung dengan menggunakan rumus Nasir Hasil ideal

\footnotetext{
$=\frac{\text { Total Frekuensi Jawaban }}{\text { Bobot tertinggi } \times \text { Jumlah pertanyaan } \times \text { Jumlah Responden }} \times 100$$$
=234
$$$$
5 \times 5 \times 23
$$$$
=234 \times 100 \%
$$

575

$$
=40,69 \longrightarrow 41 \%
$$

Jadi, nilai dari Implementasi Kebijakan Pemerintah pada Kantor Kelurahan di Kecamatan Baranti, sebesar $41 \%$ dari 100\% hasil yang diharapkan, tergolong dalam kategori "Cukup Baik"Adapun keseluruhan frekuensi dari variabel $Y$ (Disiplin Aparatur Sipil Negara) adalah 115. Untuk mengetahui jumlah persentase ideal, maka dapat dihitung dengan menggunakan rumus Nasir.

Hasil ideal

$$
\begin{aligned}
& =\frac{\text { Total Frekuensi Jawaban }}{\text { Bobot tertinggi } \times \text { Jumlah pertanyaan x Jumlah Responden }} \times 100 \\
& =\frac{115}{5} \times 13 \times 23 \\
& =\frac{115}{345} \times 100 \% \\
& =33 \%
\end{aligned}
$$

\begin{tabular}{|c|c|c|c|}
\hline \multicolumn{4}{|c|}{$\begin{array}{l}\text { MODEL REGRESI } \\
\text { variables Entered/Remowed }\end{array}$} \\
\hline Mode & $\begin{array}{l}\text { Variables } \\
\text { Entered }\end{array}$ & $\begin{array}{l}\text { Variables } \\
\text { Removed }\end{array}$ & Method \\
\hline 1 & $\begin{array}{l}\text { Implementasi } \\
\text { Kebijakan } \\
\text { Pemerintahe }\end{array}$ & . & Enter \\
\hline
\end{tabular}

Jadi, nilai dari Implementasi Kebijakan Pemerintah terhadap Disiplin Aparatur Sipil Negara pada Kantor Kelurahan di Kecamatan Baranti, sebesar $33 \%$ dari $100 \%$ hasil yang diharapkan, tergolong dalam kategori "Kurang Baik".

a. All requested variables entered.

b. Dependent Variable: Disiplin Aparatur Sipil Negara

Output ini menjelaskan tentang variabel yang dimaksud dalam model regresi diketahui bahwa variabel independen yang dimaksud adalah Implementasi Kebijakan Pemerintah dan variabel dependennya adalah Disiplin Aparatur Sipil Negara (tidak ada variabel yang dikeluarkan atau removed). Sedangkan metode regresi yang digunakan adalah Enter.

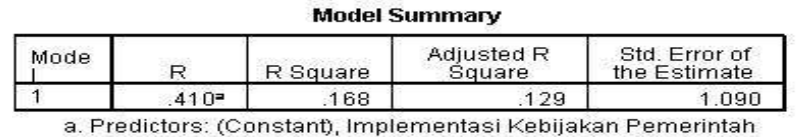

Hasil dari tabel model summary di atas menjelaskan besarnya nilai $(R)$ yaitu sebesar $0,410 \times 100 \%=41 \%$ sedangkan sisanya $100 \%-41 \%=59 \%$. Hal ini mengandung pengertian bahwa pengaruh variabel implementasi kebijakan pemerintah terhadap variabel disiplin aparatur sipil negara adalah sebesar $41 \%$ sedangkan sisanya dipengaruhi oleh faktor-faktor yang lain.

\section{SIMPULAN DAN SARAN}


Berdasarkan uraian-uraian dan pembahasan pada bab terdahulu, maka peneliti menarik kesimpulan sebagai berikut :

1. Berdasarkan dari hasil olah kuesioner diperoleh rekapitulasi dari variabel implementasi kebijakan pemerintah, diukur melalui indikator tepat kebijakan, tepat pelaksana, tepat target, tepat lingkungan, dan tepat proses, sebesar $41 \%$ termasuk dalam kategori "cukup baik".

2. Berdasarkan dari hasil olah kuesioner diperoleh rekapitulasi dari variabel disiplin aparatur sipil negara diukur melalui indikator disiplin waktu, disiplin peraturan, disiplin tanggung jawab, sebesar 33\% termasuk dalam kategori "kurang baik".

3. Berdasarkan hasil olahan analisis regresi sederhana menggunakan SPSS 16.0 for windows, dengan Model Summary diperoleh nilai sebesar $41 \%$ dengan kategori "cukup baik".

\section{E. DAFTAR PUSTAKA}

Agustino, L. 2016. Dasar-Dasar Kebijakan Publik. Bandung: Alfabeta.

Ahmad, J. 2015. Metode Penelitian Administrasi Publik Teori dan Aplikasi. Yogyakarta: Penerbit Gava Media.

Ahyari, A. 2002. Manajemen Produksi Perencanaan Sistem Produksi. Yogyakarta: BPFE.

Ali, M. 2017. Kebijakan Pendidikan Menengah dalam Perspektif Governance di Indonesia. Malang: UB Press.

Alek S. Nitisemito, 2003, Manajemen Personalia, Edisi kedua, Ghalia Indonesia, Jakarta.

Handayaningrat, S. 2006. Pengantar Studi IImu Administrasi dan Manajemen. Jakarta: Gunung Agung.

Lutfi, L. J. 2012. Hukum Dan Kebijakan Publik. Malang: Setara Press.

Moenir. 2010. Manajemen Pelayanan Umum di Indonesia. Jakarta: Bumi Aksara.

Nazir, M. 2013. Metode Penelitian. Bogor: Ghalia Indonesia.
Purba, J. 2005. Pengelolaan Lingkungan Sosial. Jakarta: Yayasan Obor Indonesia.

Nugroho D, Riant. 2012. Public Policy. Jakarta: Gramedia

Sindu Mulianto, E. R. 2006. Panduan Lengakap Supervisi Diperkaya Perspektif Syariah. Jakarta: PT ELEX Media.

Sutrisno, E. 2011. Manajemen Sumber Daya Manusia. Jakarta: Kencana Prenada Media Group.

Sugiyono. 2015. Metode Penelitian Kombinasi (Mixed Methods). Bandung: Aifabeta.

Tahir, A. 2015. Kebijakan Publik dan Transparansi Penyelenggaraan Daerah. Bandung: ALFABETA.

Tjiptono, F. 2007. Strategi Pemasaran. Yogyakarta: Andi.

Winarno, B. 2012. Kebijakan Publik (teori, proses, dan studi kasus). Yogyakarta: CAPS.

Zainuddin. 2017. Teori-Teori Mutakhir dalam Perspektif IImu Adminisstrasi Publik. Makassar: Phinatama Media.

Abdullah Ramdhani, M. A. 2017. Konsep Umum Pelaksanaan Kebijakan Publik. Jurnal Publik , 1-12.

Harahap, R. H. 2015. Pengaruh Motivasi dan Disiplin Kerja Terhadap Kinerja Pegawai di Lingkungan Balai Besar Konservasi Sumber Daya Alam. Jurnal Administrasi Publik, 1.

Sofyan, A, A. J., \& Sunarti. 2019. Pengaruh Budaya Kerja Terhadap Kedisiplinan Pegawai Di Kantor Desa Bina Baru Kecamatan Kulo Kabupaten Sidenreng Rappang. Jurnal Moderat , 56-69.

Fitrianingrum, E. D. 2015. Pengaruh Pengawasan terhadap Disiplin Kerja Pegawai pada Kantor Kecamatan Samarinda Ulu Kota Samarinda. ejurnal Administrasi Negara , 16441655. 
Sari, Y. 2015. Implementasi Peraturan Pemerintah Nomor 53 Tahun 2010 tentang Disiplin Pegawai Negeri Sipil di Kecamatan Samarinda Utara. ejurnal IImu Pemerintahan , 1-11.

Njima, M. 2016. Implementasi Kebijakan Disiplin Pegawai Negeri Sipil pada Kantor Kecamatan Totikum Selatan Kabupaten Banggai Kepulauan. ejurnal Katalogis , 156-168.
Juliarso, A. 2016. Implementasi Peraturan Pemerintah Nomor 53 Tahun 2010 Tentang Disiplin Pegawai Negeri Sipil oleh Camat di Kantor Kecamatan Cijeungjing Kabupaten Ciamis. ejurnal Administrasi Negara , 48-55.

Undang-Undang Nomor 5 tahun 2014 tentang Aparatur Sipil Negara

Peraturan Pemerintah Nomor 53 tahun 2010 tentang Disiplin PegawaiNegeri Sipil 